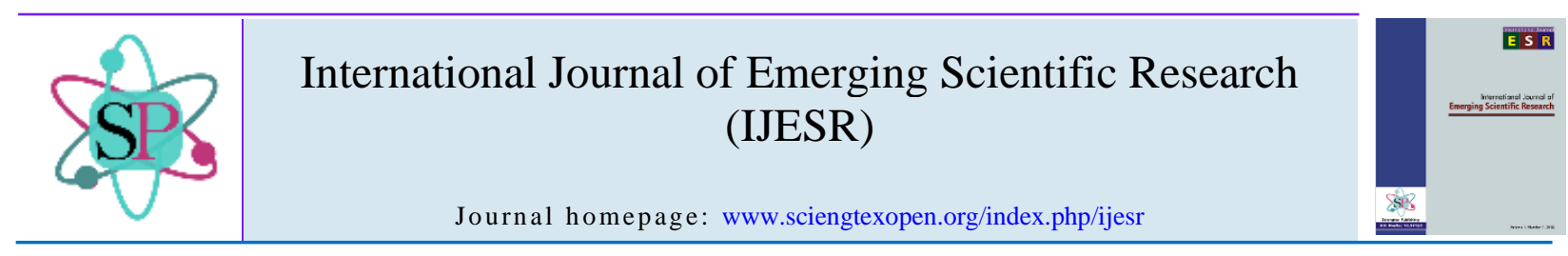

\title{
Thermodynamic Studies on the Sorption of Lead (II), Chromium (III) and Manganese (II) ions onto Acid-Activated Shale
}

\author{
I. R. Ilaboya (i) a,*, J. S. Okpoko ${ }^{\text {b }}$ \\ ${ }^{a}$ Department of Civil Engineering, University of Benin, P.M.B. 1154, Benin City, Nigeria \\ ${ }^{b}$ Department of Civil Engineering, Benson Idahosa University, P.M.B. 1100, Benin City, Nigeria
}

\section{Authors' Contributions}

This work was carried out in collaboration between authors. The revised manuscript was read and approved by all authors.

\section{ARTICLE INFO}

Article history:

Received 23 April 2021

Received in revised form

2 June 2021

Accepted 4 June 2021

Available online

6 June 2021

Keywords:

Adsorbent

Adsorption temperature

Chemical analysis

Microstructural arrangement

Thermodynamic parameters

\section{ABSTRACT}

Shale mineral in its raw form was collected, processed, calcinated and activated using tetraoxosulphate (VI) acid. The microstructural arrangement and chemical composition of the raw, calcinated and acid-activated shale was determined using $\mathrm{X}$ ray fluorescence and scanning electron microscope to verify its ability for the removal of $\mathrm{Pb}^{2+}, \mathrm{Cr}^{3+}$ and $\mathrm{Mn}^{2+}$ from wastewater. Batch experimental method was used to study the effect of different adsorption parameters on the sorption efficiency of shale. The effect of temperature on the sorption of $\mathrm{Pb}^{2+}, \mathrm{Cr}^{3+}$ and $\mathrm{Mn}^{2+}$ on acid-activated shale was investigated at varied temperature of $15-40^{\circ} \mathrm{C}$. The calculated value of enthalpy $\left(\Delta H^{\circ}\right)$ was $12.50 \mathrm{~kJ} / \mathrm{mol}$ for $\mathrm{Pb}^{2+}$ adsorption, $5 \mathrm{~kJ} / \mathrm{mol}$ for $\mathrm{Cr}^{3+}$ and $11 \mathrm{~kJ} / \mathrm{mol}$ for $\mathrm{Mn}^{2+}$ adsorption. The calculated values of Gibbs free energy $\left(\Delta G^{\circ}\right)$ varies from $-6.576 \mathrm{~kJ} / \mathrm{mol}$ to $1.358 \mathrm{~kJ} / \mathrm{mol}$ for $\mathrm{Pb}^{2+}$ adsorptions, from $-2.696 \mathrm{~kJ} / \mathrm{mol}$ to $0.192 \mathrm{~kJ} / \mathrm{mol}$ for $\mathrm{Cr}^{3+}$ adsorptions, and $-4.994 \mathrm{~kJ} / \mathrm{mol}$ to $1.870 \mathrm{~kJ} / \mathrm{mol}$ for $\mathrm{Mn}^{2+}$ adsorptions. The entropy $\left(\Delta S^{\circ}\right)$ range is $38.68-60.946 \mathrm{~kJ} / \mathrm{mol}$ for $\mathrm{Pb}^{2+}$ adsorptions, $16.69-24.58 \mathrm{~kJ} / \mathrm{mol}$ for $\mathrm{Cr}^{3+}$ adsorptions, and $31.70-51.10 \mathrm{~kJ} / \mathrm{mol}$ for $\mathrm{Mn}^{2+}$ adsorptions. The positive value of $\Delta H^{\circ}$ shows that the adsorption of $\mathrm{Pb}^{2+}, \mathrm{Cr}^{3+}$ and $\mathrm{Mn}^{2+}$ onto acid-activated shale was an endothermic process. The values of $\Delta G^{\circ}$ are negative at temperature of $298 \mathrm{~K}$ and above for the three metal ions studied, which confirmed that the adsorption of $\mathrm{Pb}^{2+}$, $\mathrm{Cr}^{3+}$ and $\mathrm{Mn}^{2+}$ on acid-activated shale was a spontaneous process. The decline in $\Delta G^{\circ}$ with increasing adsorption temperature showed that adsorptions of $\mathrm{Pb}^{2+}, \mathrm{Cr}^{3+}$ and $\mathrm{Mn}^{2+}$ onto acid-activated shale became better at higher temperature while the positive value of $\Delta S^{\circ}$ for all metal ions studied showed the amplified arbitrariness at the solid-solution interface during the fixation of the adsorbate on the active site of acid-activated shale.

\section{Introduction}

The economic advancement of a country depends not only on the health status of the people but also on how free the environment is from disease [1]. One of the critical environmental pollution is the continuous discharge of untreated wastewater in our environment. Wastewater is any water, which has been adversely influenced in quality by anthropogenic activities of man. It encompasses liquid waste discharged by residential buildings, commercial estates, industries, and/or agriculture and can involve a broad variety of potential pollutants such as metal ions, which are vital for human beings at low concentrations but they are toxic or even carcinogenic at high concentrations [2].

\footnotetext{
* Corresponding author

E-mail address: rudolph.ilaboya@uniben.edu

https://doi.org/10.37121/ijesr.v2.158
} 
The discharge of untreated effluents from different industries comprising mining, fertilizer and pesticide industry has become a major issue of serious concern owing to their high level of toxicity [3-4]. Research into the effective removal of these toxic heavy metals from wastewater is fast growing and has developed into a widely studied area. There are numerous conventional technologies such as chemical precipitation, electrolytic precipitation, solvent extraction, ion exchange and reverse osmosis, have been developed to remove these heavy metals from wastewater [5]. However, these physico-chemical processes have significant shortcomings of being highly expensive and complex. In addition, the chemical by-products from some of this technology can be disruptive to the environment causing harmful effects to plants, animal and even humans [6-7].

Attempts have been made by different scholars to develop alternate low-cost techniques for heavy metal removal [8-11]. Among them, the treatment of wastewaters with activated carbon is considered an effective technique for the removal of metal ions from wastewater [12-17]. An investigation into the performance of cassava peel as adsorbent for wastewater treatment was conducted and reported by Ilaboya et al. [12]. In their study, activated carbon from cassava peel was prepared and characterized for different physico-chemical properties, namely, volatile matter, moisture content, iodine number, methylene blue number, surface area, fixed carbon, micropore as well as total pore volume. The effect of various adsorption parameters such as contact time, adsorbent dosage, and adsorption temperature in addition to the $\mathrm{pH}$ were considered to optimize the conditions for the maximum adsorption. The adsorption mechanism was studied with the aid of selected kinetic models (Elovich, pseudo-first order, and pseudo-second order model) while the equilibrium relationship between the amount of lead and copper adsorbed and the amount left in the system was investigated using the popular Langmuir, Freundlich and Temkin isotherm models. To understand the thermodynamics of the adsorption process, the value of the enthalpy $\left(\Delta \mathrm{H}^{\circ}\right)$, entropy $\left(\Delta \mathrm{S}^{\circ}\right)$ and the Gibbs free energy $\left(\Delta \mathrm{G}^{\circ}\right)$ were calculated using simple mathematical equations. Results indicated that the adsorption of copper and lead ions onto activated cassava peels is endothermic in nature owing to the positive value of $\Delta \mathrm{H}^{\circ}$. The computed values of $\Delta \mathrm{G}^{\circ}$ were observed to be negative at $298 \mathrm{~K}$ and above as anticipated for spontaneous process. The decreasing value of $\Delta \mathrm{G}^{\circ}$ with increasing adsorption temperature indicates that the adsorption became better with increasing temperature. The positive value of $\Delta \mathrm{S}^{0}$ shows the increased variability at the solid-solution interphase during the fixation of the adsorbate ion (copper and lead) on the active site of the adsorbent.

In this paper, adsorption thermodynamic study was done to understand the type and nature of reaction that accompanied the sorption of $\mathrm{Pb}^{2+}, \mathrm{Cr}^{3+}$ and $\mathrm{Mn}^{2+}$ onto acid-activated shale. The objectives were to find out if the reaction was endothermic or exothermic, and spontaneous or non-spontaneous coupled with the degree of randomness associated with the adsorption process. To compute the thermodynamic parameters such as $\Delta \mathrm{H}^{\circ}$, $\Delta \mathrm{S}^{\circ}$ and $\Delta \mathrm{G}^{\circ}$, the effect of temperature on the sorption of $\mathrm{Pb}^{2+}, \mathrm{Cr}^{3+}$ and $\mathrm{Mn}^{2+}$ on acid-activated shale was investigated under varied temperature of $15-40^{\circ} \mathrm{C}$.

\section{Methodology}

\subsection{Sample Collection and Preparation}

Shale was collected from its deposit at Okada (see Fig. A1, Appendix A), Edo State, Nigeria. First, the shale was soaked with $5 \%$ hydrogen peroxide in a plastic container to get rid of any carbonaceous matter, which can interfere with the metal adsorption ability of the shale. Then, it was washed with distilled water before been dried in hot air oven at $50-70{ }^{\circ} \mathrm{C}$ for $8 \mathrm{~h}$. The dried shale was cut to fine particles and screen sieved with a sieve size of $212 \mu \mathrm{m}$ before usage [18]. For calcination, $500 \mathrm{~g}$ of the processed shale was put in a furnace at 550 ${ }^{\circ} \mathrm{C}$ for $10 \mathrm{~h}$ and thereafter placed in a desiccator to cool before use.

For acid-activation, $200 \mathrm{~g}$ of the calcinated shale was mixed with 1 liter of $0.25 \mathrm{M}$ sulfuric acid. The mixture was heated at $105^{\circ} \mathrm{C}$ for $30 \mathrm{~min}$, slowly cooled, filtered and washed free of acid using distilled water as indicated by a $\mathrm{pH}$ meter. The shale was dried at a temperature of $100{ }^{\circ} \mathrm{C}$ for $30-45 \mathrm{~min}$, ground using mortar and pestle, sieved to $212 \mu \mathrm{m}$ and stored in a desiccator before use. The acid activated shale was then characterized using scanning electron microgram (SEM) and $x$-ray florescence (XRF). The list of equipment used in sample preparation and characterization has been described in previous study [19].

\subsection{Characterization of Adsorbent}

The surface microstructure of the shale was observed using SEM (APEX 3020 PSEM 2). The chemical composition of shale was analyzed using XRF APEX 3022. A mixture (1:1) of $0.025 \mathrm{M}$ solution of hydrochloric acid and nitric acid was prepared. Then, a mixture (1:10) of the solid adsorbent to acid solution was taken and stirred for $30 \mathrm{~min}$. The resulting solution was filtered and the filtrate was utilized for the analysis [20]. 


\subsection{Preparation of Aqueous Solution}

The chemicals utilized were analytical grade. Stock solution of lead and manganese were prepared by dissolving correct amounts of $\mathrm{Pb}\left(\mathrm{NO}_{3}\right)_{2}$ and $\mathrm{MnCl}_{2} \cdot 4 \mathrm{H}_{2} \mathrm{O}$ in a liter of distilled water. All working solutions were obtained by diluting the stock solution with distilled water and the concentration of metal ion present in solution was analyzed by the Atomic Absorption Spectrophotometer (AAS).

\subsection{Adsorption Analyzes}

Adsorption study was performed to determine the effect of adsorption temperature on the sorption of studied metals ions onto acid-activated shale using batch adsorption method. The experiment was carried out at varied adsorption temperatures $(288,298,303$ and $313 \mathrm{~K})$. A $250 \mathrm{ml}$ conical flask containing the adsorbent and $50 \mathrm{ml}$ solution of the aqueous media containing the metal ion was stirred at $150 \mathrm{rpm}$ by a mantle fitted with magnetic stirrer. The $\mathrm{pH}$ value of the aqueous media was kept at optimal value for each metal. The separation of the adsorbent from the aqueous media containing the heavy metal was carried out by filtration using $150 \mathrm{~mm}$ Whatman filter paper [19]. The filtrate was then stored in a sample can and placed in a refrigerator before analysis. The residual metal ion concentration was deduced using the AAS. The mass balance equation was used to determine the amount of heavy metal ions removed during the series of batch examination as [21]:

$q=\frac{v}{m}\left[C_{0}-C_{e}\right]$.

Where, $q(\mathrm{mg} / \mathrm{g})$ defines the metal uptake, $C_{0}(\mathrm{mg} / \mathrm{l})$ and $C_{\mathrm{e}}(\mathrm{mg} / \mathrm{l})$ are the initial and equilibrium metal ion concentrations, $v(\mathrm{ml})$ is the aqueous sample volume and $m(\mathrm{~g})$ is the mass of adsorbent used.

\subsection{Thermodynamic Studies}

Thermodynamic study was done to understand the nature of the reaction, the degree of randomness and the spontaneity of the process involved in the sorption of lead, chromium and manganese ions onto shale. Thermodynamic parameters employed are presented in Table 1 . Thermodynamic parameters $\left(\Delta \mathrm{G}^{0}, \Delta \mathrm{H}^{0}\right.$ and $\Delta \mathrm{S}^{0}$ ) for $\mathrm{Pb}^{2+}, \mathrm{Cr}^{3+}$ and $\mathrm{Mn}^{2+}$ adsorption onto acid-activated shale were computed from equations presented in Table 1.

Table 1 Definition of selected thermodynamic parameters.

\begin{tabular}{ccc}
\hline Parameter & Equation & Reference \\
\hline$K_{\mathrm{c}}$ & $K_{C}=\frac{K_{1}}{K_{2}}=\frac{C_{L}}{C_{S}}$ & [22] \\
$\Delta \mathrm{H}^{\circ}$ & $\ln K_{C}=\left[\frac{-\Delta H^{0}}{R T}\right]$ & {$[23]$} \\
$\Delta \mathrm{G}^{\circ}$ & $\Delta G^{0}=\left[-R T \ln K_{C}\right]$ & {$[23]$} \\
$\Delta \mathrm{S}^{\circ}$ & $\Delta S^{0}=\left[\frac{\left(\Delta H^{0}-\Delta G^{0}\right)}{T}\right]$ & {$[22,23]$} \\
\hline
\end{tabular}

Where, $K_{\mathrm{c}}\left(\mathrm{gm} / \mathrm{g}\right.$-min) is the adsorption equilibrium constant, $K_{1}(\mathrm{gm} / \mathrm{g}-\mathrm{min})$ is adsorption rate constant, $K_{2}(\mathrm{gm} / \mathrm{g}$-min) is desorption rate constant, $C_{\mathrm{L}}(\mathrm{mg} / \mathrm{l})$ is equilibrium concentration of metal ion in solution, $C_{\mathrm{S}}(\mathrm{mg} / \mathrm{g})$ is residual metal ion concentration, $R(\mathrm{~J} / \mathrm{gmol}-\mathrm{K})$ is the gas constant, and $T\left({ }^{\circ} \mathrm{C}\right)$ is the adsorption temperature

\section{Results and Discussion}

\subsection{Adsorbent Characterization}

Result of the microstructural and chemical analysis of the raw shale, calcinated shale and acid-activated shale are presented in Fig. 1 and Table 2. SEM result can provide adequate information on the morphology and topological presentations of the shale. Such presentations can also give possible explanations of the solid behavior [20]. SEM was taken to confirm the presence of microspores in the shale structure. It was observed from Fig. 1 that the surface features of the shale materials change severely with calcination as well as acid treatment with the acid-treated shale shows a better irregular porous surface structure. The explanation is that calcination followed by acid treatment tends to open up the pore spaces better than calcination alone. The larger number of microporous structures seen with acid-activated shale indicates a higher surface area. It was observed from Table 2 that silicon oxide and aluminum oxide are the dominant oxides present in shale. The alumina composition of the raw shale was observed to be $21.33 \mathrm{wt} \%$, it increases to $24.41 \mathrm{wt} \%$ for the calcinated shale and decreases to $18.13 \mathrm{wt} \%$ for the acid-activated shale apparently due to the acid dealumination of the shale resulting from the effects of acidification as relates to the works of [21]. 
Table 2 Result of Chemical Composition.

\begin{tabular}{cccc}
\hline Oxides & $\begin{array}{c}\text { Raw Shale } \\
\text { (Wt. \%) }\end{array}$ & $\begin{array}{c}\text { Calcinated Shale } \\
\text { (Wt. \%) }\end{array}$ & $\begin{array}{c}\text { Acid-Activated Shale } \\
\text { (Wt. \%) }\end{array}$ \\
\hline $\mathrm{SiO}_{2}$ & 49.53 & 54.47 & 57.19 \\
$\mathrm{Al}_{2} \mathrm{O}_{3}$ & 21.33 & 24.41 & 18.13 \\
$\mathrm{TiO}_{2}$ & 1.36 & 1.18 & 2.17 \\
$\mathrm{Fe}_{2} \mathrm{O}_{3}$ & 2.74 & 2.09 & 0.28 \\
$\mathrm{MgO}$ & 1.73 & 1.14 & 1.63 \\
$\mathrm{MnO}$ & 0.06 & 0.05 & 0.04 \\
$\mathrm{CaO}$ & 2.23 & 2.03 & 1.64 \\
$\mathrm{Na} 2$ & 2.21 & 1.87 & 1.56 \\
$\mathrm{~K}_{2} \mathrm{O}$ & 2.11 & 2.26 & 2.03 \\
$\mathrm{P}_{2} \mathrm{O}_{5}$ & 0.54 & 1.23 & 0.32 \\
$\mathrm{Si} / \mathrm{Al}_{3}$ & 1.581 & 2.231 & 3.154 \\
\hline
\end{tabular}

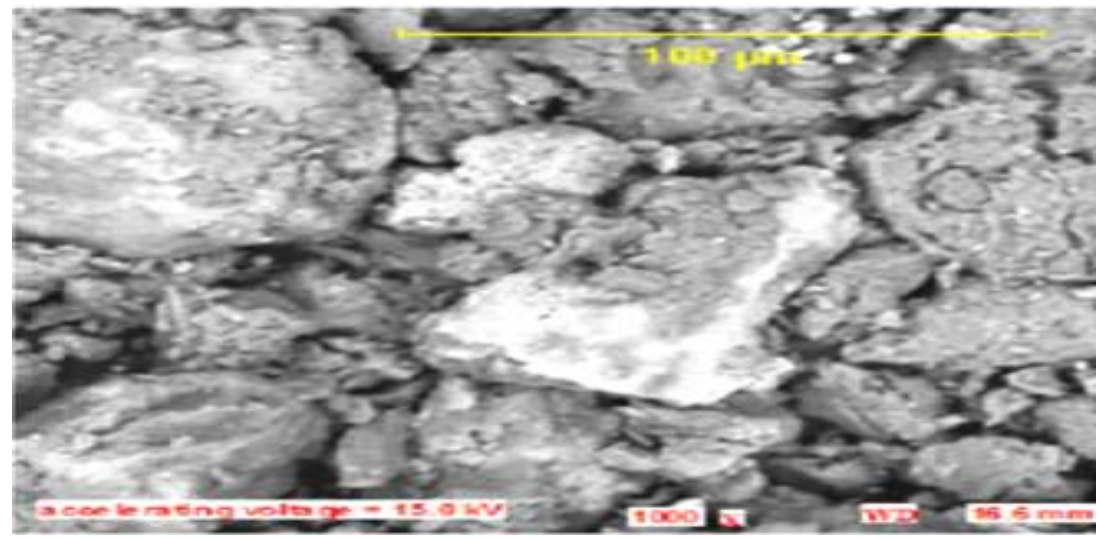

(a)

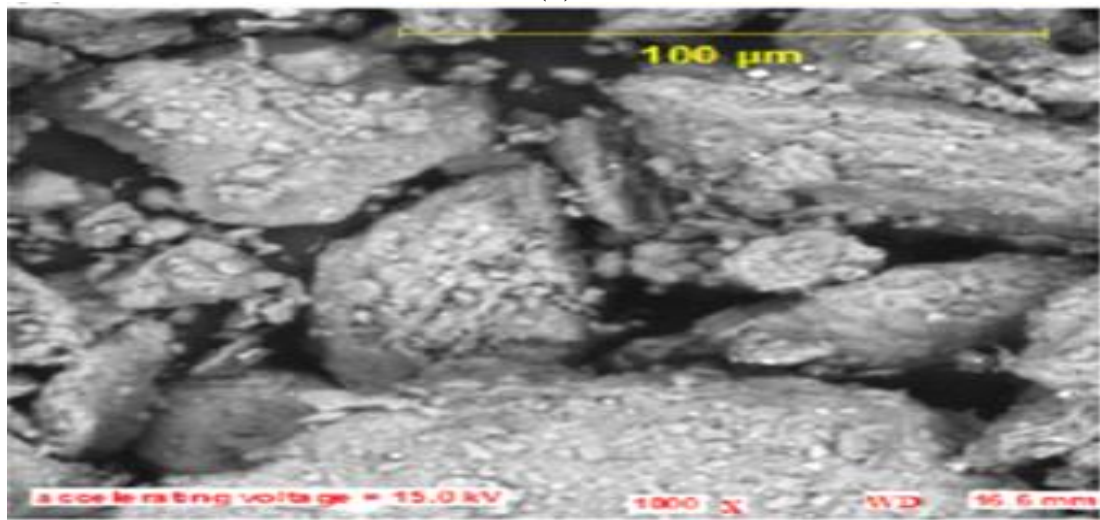

(b)

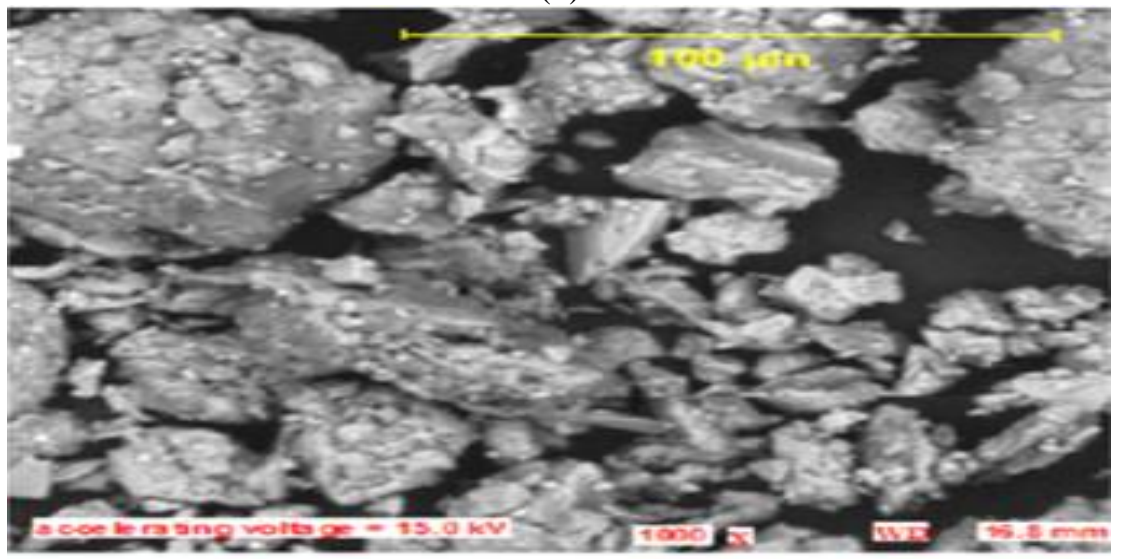

(c)

Fig. 1 SEM (a) raw shale (b) calcinated shale (c) acid-activated shale. 


\subsection{Adsorbent Characterization}

The influence of temperature on the sorption of $\mathrm{Pb}^{2+}, \mathrm{Cr}^{3+}$ and $\mathrm{Mn}^{2+}$ on acid activated shale investigated under varied condition of $15-40^{\circ} \mathrm{C}$ is analyzed in Figs. $2-4$, respectively.

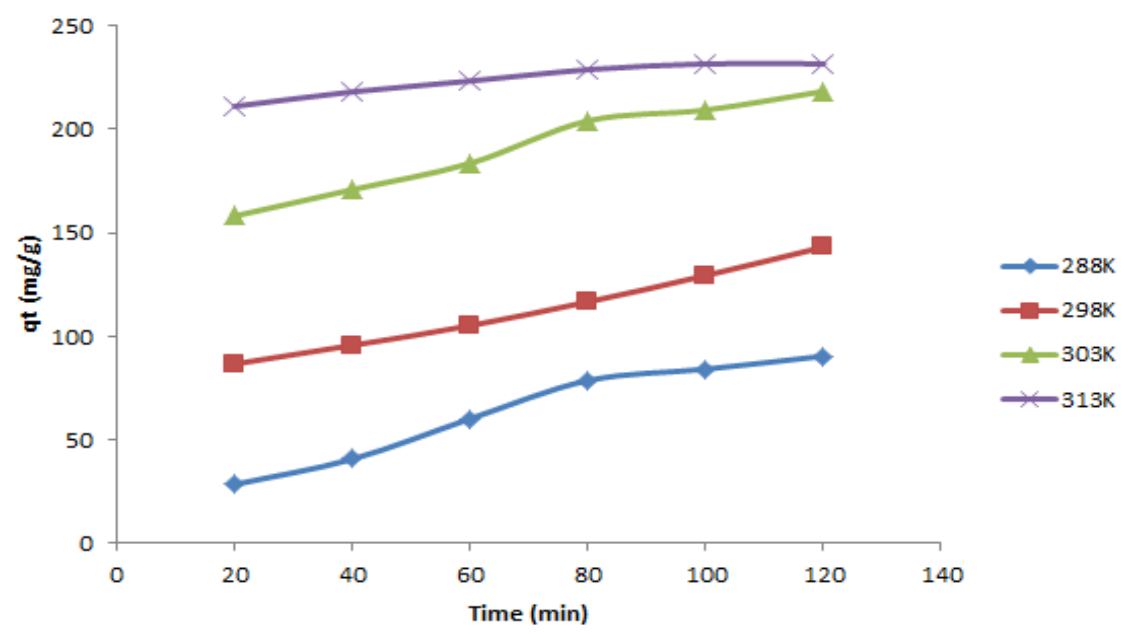

Fig. 2 Influence of temperature on the sorption of $\mathrm{Pb}(\mathrm{II})$ ion onto acid-activated shale at $\mathrm{pH}$ of 8 , dose $1 \mathrm{~g}$, agitation $150 \mathrm{rpm}$, and initial metal ion concentration of $5 \mathrm{mg} / \mathrm{l}$.

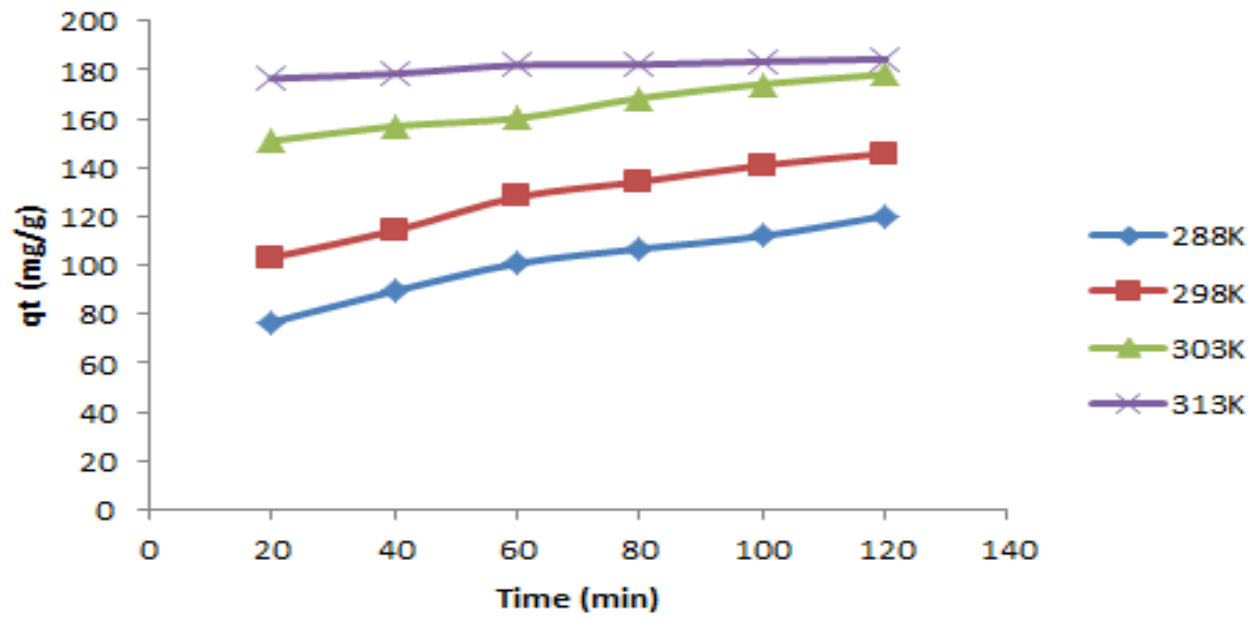

Fig. 3 Influence of temperature on the sorption of $\mathrm{Cr}(\mathrm{III})$ ion onto acid-activated shale at $\mathrm{pH}$ of 6 , dose $1 \mathrm{~g}$, agitation $150 \mathrm{rpm}$, and initial metal ion concentration of $5 \mathrm{mg} / \mathrm{l}$.

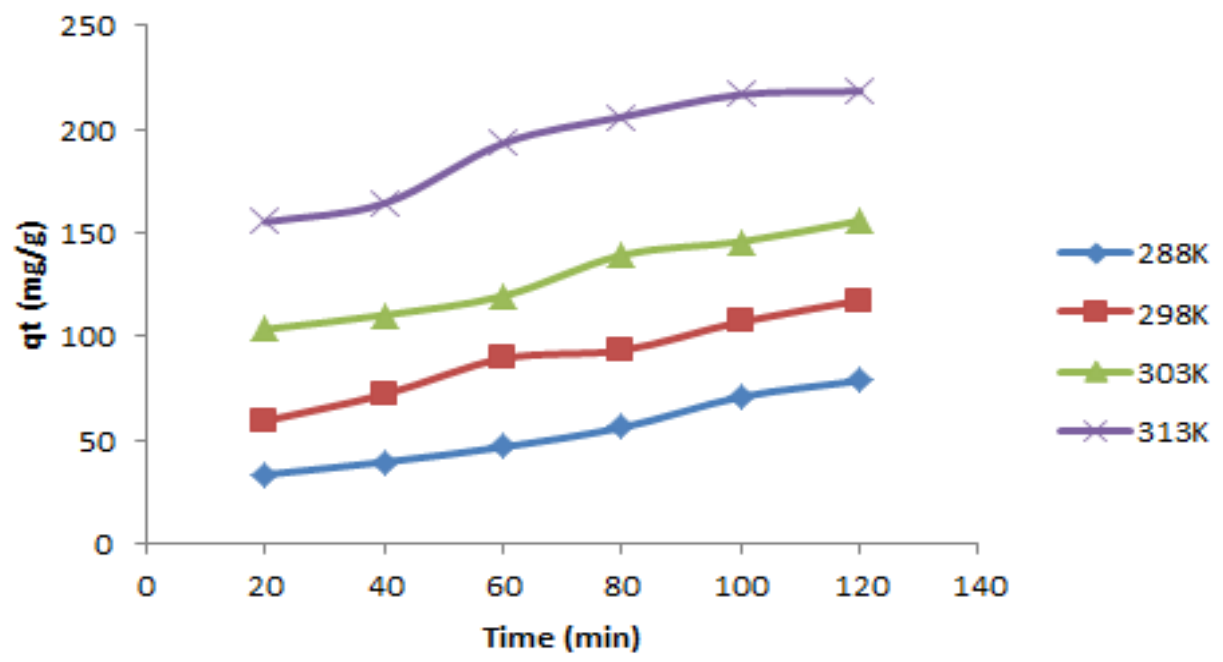

Fig. 4 Influence of temperature on the sorption of $\mathrm{Mn}(\mathrm{II})$ ion onto acid-activated shale at $\mathrm{pH}$ of 8 , dose $1 \mathrm{~g}$, agitation $150 \mathrm{rpm}$, and initial metal ion concentration of $5 \mathrm{mg} / \mathrm{l}$. 
Results of Figs. $2-4$, show that temperature variation influenced the amount of $\mathrm{Pb}^{2+}, \mathrm{Cr}^{3+}$ and $\mathrm{Mn}^{2+}$ adsorption, respectively. At high temperature, the diffusion of metal ions through the adsorbent pores was faster and can advance to a greater extent as reported by [11]. The equilibrium constant for the sorption of $\mathrm{Pb}^{2+}, \mathrm{Cr}^{3+}$ and $\mathrm{Mn}^{2+}$ adsorption onto acid activated shale were computed at different temperatures for equilibrium adsorption time of $120 \mathrm{~min}$ and result is presented in Table 3. The variation of equilibrium constant with temperature for $\mathrm{Pb}^{2+}, \mathrm{Cr}^{3+}$ and $\mathrm{Mn}^{2+}$ ions adsorption onto acid activated shale is presented in Fig. 5. Results of Fig. 5 showed that adsorption $K_{\mathrm{C}}$ increases with increase in adsorption temperature for $\mathrm{Pb}^{2+}, \mathrm{Cr}^{3+}$ and $\mathrm{Mn}^{2+}$ adsorption thus implying a consolidation of the adsorbate-adsorbent interactions with rising adsorption temperature. Values of $\Delta \mathrm{H}^{0}$ were calculated from the slope of the linear variation of $\ln K_{C}$ against the reciprocal of adsorption temperature (1/T) presented in Fig. 6.

Table 3 Equilibrium constant (Kc) computation for $\mathrm{Pb}^{2+}, \mathrm{Cr}^{3+}$ and $\mathrm{Mn}^{2+}$ adsorption.

\begin{tabular}{ccccccccc}
\hline Adsorbate & $\begin{array}{c}\text { Temp. } \\
(\mathrm{K})\end{array}$ & $\begin{array}{c}\mathrm{C}_{\mathrm{o}} \\
(\mathrm{mg} / \mathrm{l})\end{array}$ & $\begin{array}{c}\mathrm{C}_{\mathrm{e}} \\
(\mathrm{mg} / \mathrm{l})\end{array}$ & $\begin{array}{c}\left(\mathrm{C}_{\mathrm{o}}-\mathrm{C}_{\mathrm{e}}\right) \\
(\mathrm{mg} / \mathrm{l})\end{array}$ & $\mathrm{F}=\frac{C_{o}-C_{e}}{C_{o}}$ & $(1-\mathrm{F})$ & $\mathrm{Kc}=\left(\frac{F}{1-F}\right)$ & $\ln K_{\mathrm{C}}$ \\
\hline \multirow{6}{*}{$\mathrm{Pb}^{2+}$} & 288 & 5.0 & 3.19 & 1.81 & 0.362 & 0.638 & 0.567 & -0.567 \\
& 298 & 5.0 & 2.14 & 2.86 & 0.572 & 0.428 & 1.336 & 0.290 \\
& 303 & 5.0 & 0.63 & 4.37 & 0.874 & 0.126 & 6.937 & 1.937 \\
& 313 & 5.0 & 0.37 & 4.63 & 0.926 & 0.074 & 12.514 & 2.527 \\
\hline \multirow{4}{*}{$\mathrm{Cr}^{3+}$} & 288 & 5.0 & 2.60 & 2.4 & 0.48 & 0.52 & 0.923 & -0.080 \\
& 298 & 5.0 & 2.09 & 2.91 & 0.582 & 0.418 & 1.392 & 0.331 \\
& 303 & 5.0 & 1.44 & 3.56 & 0.712 & 0.288 & 2.472 & 0.905 \\
& 313 & 5.0 & 1.31 & 3.69 & 0.738 & 0.262 & 2.817 & 1.036 \\
\hline \multirow{6}{*}{$\mathrm{Mn}^{2+}$} & 288 & 5.0 & 3.43 & 1.57 & 0.314 & 0.686 & 0.458 & -0.781 \\
& 298 & 5.0 & 2.66 & 2.34 & 0.468 & 0.532 & 0.880 & -0.128 \\
& 303 & 5.0 & 1.89 & 3.11 & 0.622 & 0.378 & 1.646 & 0.498 \\
& 313 & 5.0 & 0.64 & 4.36 & 0.872 & 0.128 & 6.813 & 1.919 \\
\hline
\end{tabular}

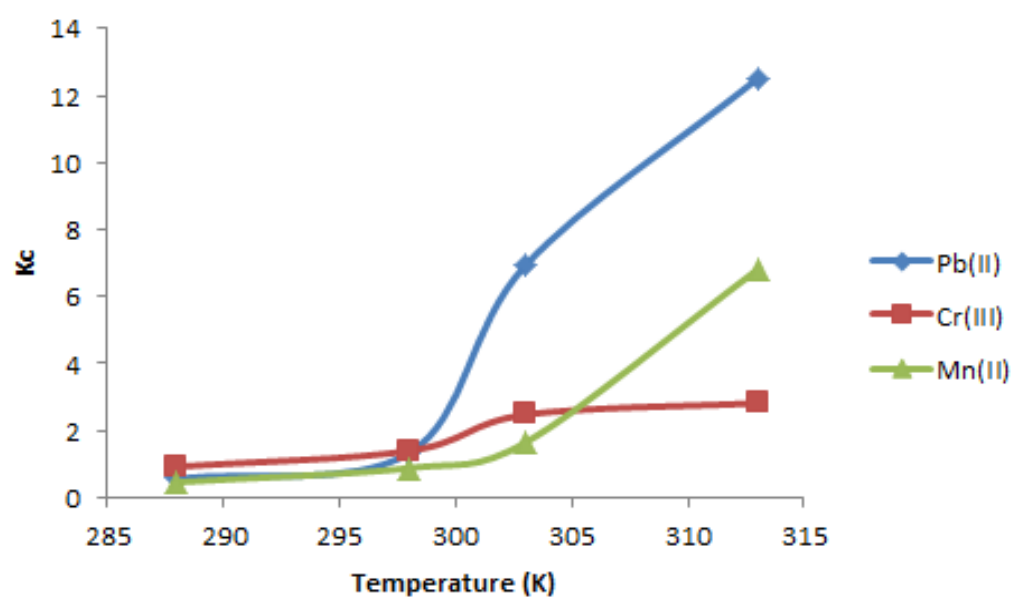

Fig. 5 Variation of $K_{\mathrm{c}}$ with temperature for $\mathrm{Pb}^{2+}, \mathrm{Cr}^{3+}$ and $\mathrm{Mn}^{2+}$ adsorption onto acid-activated shale.

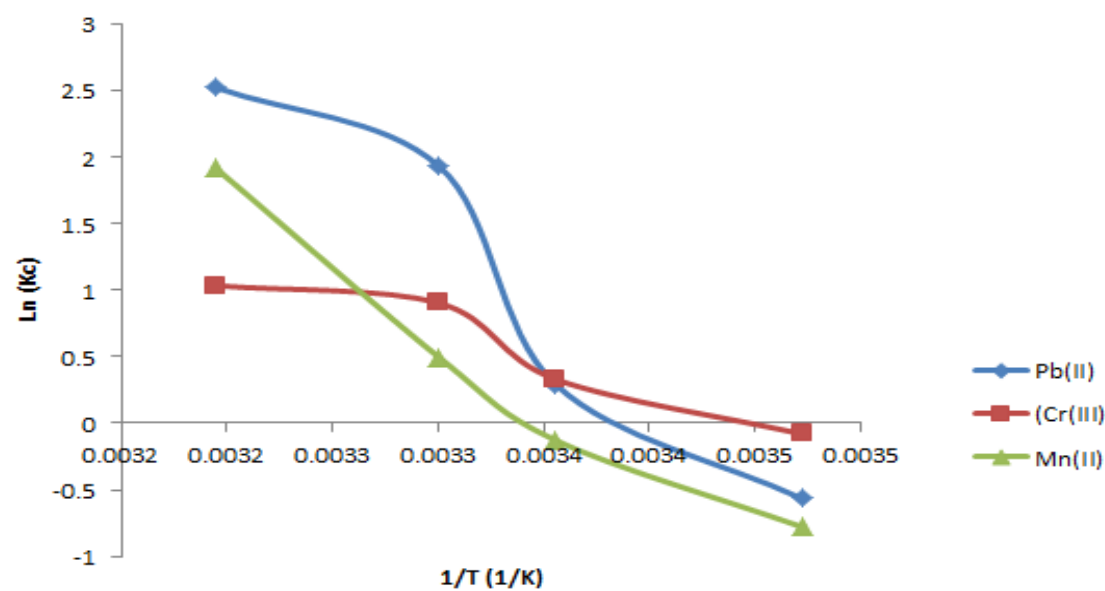

Fig. 6 Variation of $\ln K_{C}$ against the reciprocal of adsorption temperature. 
Result obtained from the computation of thermodynamic parameters $\left(\Delta \mathrm{G}^{0}, \Delta \mathrm{H}^{0}\right.$ and $\left.\Delta \mathrm{S}^{0}\right)$ for $\mathrm{Pb}^{2+}, \mathrm{Cr}^{3+}$ and $\mathrm{Mn}^{2+}$ adsorption onto acid activated shale is shown in Table 4.

Table 4 Thermodynamic variables $\left(\Delta \mathrm{H}^{0}, \Delta \mathrm{G}^{0}\right.$ and $\left.\Delta \mathrm{S}^{0}\right)$ for lead, chromium and manganese ion adsorption onto acid activated shale.

\begin{tabular}{ccccc}
\hline \multirow{3}{*}{ Adsorbate } & \multicolumn{4}{c}{ Thermodynamic Parameters } \\
\cline { 2 - 5 } & Temperature & $\begin{array}{c}\Delta \mathrm{H}^{\circ} \\
(\mathrm{KJ} / \mathrm{mol})\end{array}$ & $\begin{array}{c}\Delta \mathrm{G}^{\circ} \\
(\mathrm{kJ} / \mathrm{mol})\end{array}$ & $\begin{array}{c}\Delta \mathrm{S}^{\circ} \\
(\mathrm{J} / \mathrm{k} . \mathrm{mol})\end{array}$ \\
\hline $\mathrm{Pb}^{2+}$ & 288 & 12.5 & 1.358 & 38.680 \\
& 298 & & -0.718 & 44.357 \\
& 303 & & -4.880 & 57.358 \\
& 313 & 5.0 & -6.576 & 60.946 \\
\hline $\mathrm{Cr}^{3+}$ & 288 & & 0.192 & 16.690 \\
& 298 & & -0.820 & 19.530 \\
& 303 & 11.0 & -2.280 & 24.020 \\
$\mathrm{Mn}^{2+}$ & 313 & & -2.696 & 24.580 \\
& 288 & & 1.870 & 31.701 \\
& 298 & & 0.317 & 35.849 \\
& 303 & -1.255 & 40.444 \\
& 313 & -4.994 & 51.098 \\
\hline
\end{tabular}

The positive value of $\Delta \mathrm{H}^{0}$ observed in Table 4 shows that the adsorption of $\mathrm{Pb}^{2+}, \mathrm{Cr}^{3+}$ and $\mathrm{Mn}^{2+}$ onto acidactivated shale was an endothermic process. The values of $\Delta \mathrm{G}^{\circ}$ are negative at temperature of $298 \mathrm{~K}$ and above for the three metal ions studied which confirmed that the adsorption of $\mathrm{Pb}^{2+}, \mathrm{Cr}^{3+}$ and $\mathrm{Mn}^{2+}$ onto acid-activated shale was a spontaneous process. The decline in $\Delta \mathrm{G}^{\circ}$ with rising adsorption temperature revealed that adsorption of $\mathrm{Pb}^{2+}, \mathrm{Cr}^{3+}$ and $\mathrm{Mn}^{2+}$ onto acid activated shale became better at higher temperature [24]. The positive value of $\Delta \mathrm{S}^{0}$ for all metal ion studied revealed the enlarged variability at the solid-solution interface during the fixation of the adsorbate on the active site of acid-activated shale. Results deduced from this study is in line with the works of Qadeer and Hanif [22], which reported a positive of $\Delta S^{0}$ for the adsorption of zirconium ions on activated charcoal from aqueous solution.

\section{Conclusion}

The study was conducted to investigate the potential of using shale as adsorbent for $\mathrm{Pb}^{2+}, \mathrm{Cr}^{3+}$ and $\mathrm{Mn}^{2+}$ adsorption. Results of this study have shown that shale, particularly acid activated and calcinated shale are highly effective for the treatment of wastewater containing $\mathrm{Pb}^{2+}, \mathrm{Cr}^{3+}$ and $\mathrm{Mn}^{2+}$. The relative abundance of shale within our local environment makes it even better. These will help in addressing the health hazards caused by the occurrence of these metals as well as the difficulties of preparing commercial activated carbon by indigenous industries involved in wastewater treatment. The positive value of $\Delta \mathrm{S}^{0}$ for the three metals ions studied showed the increased randomness at the solid-solution interface during the fixation of the adsorbate ion while the negative values of $\Delta \mathrm{G}^{0}$ at higher temperature showed the spontaneous nature of the process and the dependence of adsorption on temperature.

\section{Appendix A}

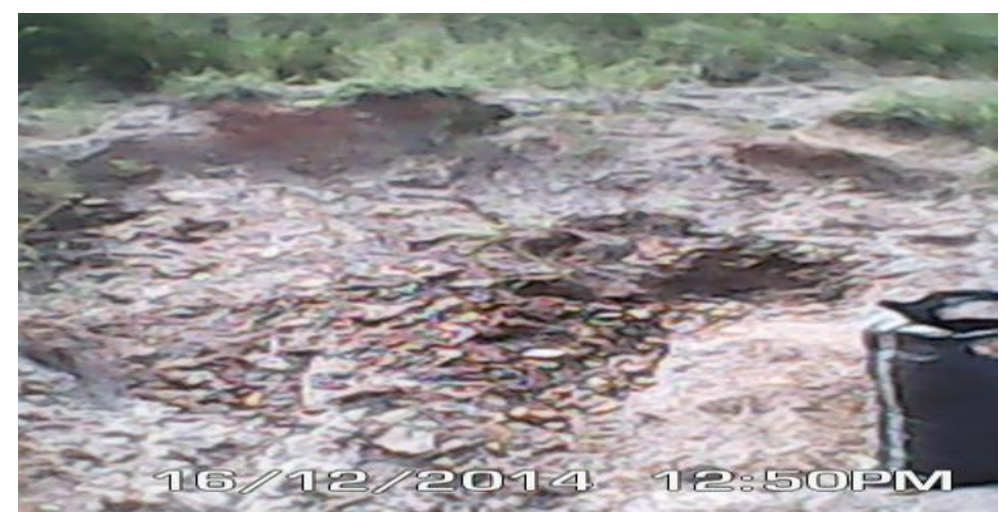

Fig. A1 A Large Deposit of Shale in Okada.

\section{Conflict of Interests}

The authors declare that there is no conflict of interests regarding the publication of this paper. 


\section{ORCID}

I. R. Ilaboya (ii) https://orcid.org/0000-0002-8982-7404

\section{References}

[1] A. A. Basheer, "Chemical chiral pollution: Impact on the society and science and need of the regulations in the $21 \mathrm{st}$ century”, Wileyonlinelibrary.com/journal/chir, Chirality, vol. 1, pp. 1-5, 2017.

[2] I, Ali, V. K. Gupta and H. Y. Aboul-Enein, "Metal ion speciation and capillary electrophoresis: Application in the new millennium, Electrophoresis, vol. 26, pp. 3988-4002, 2005.

[3] M. S. Mohammad, and S. Ali, "Modeling of equilibrium data for free cyanide adsorption onto activated carbon by linear and non-linear regression method," International Conference on Environment and Industrial Innovation Singapore, vol. 12, pp. 79-84, 2011.

[4] S. Shahmohammadi-Kalalagh, and H. Babazadeh, "Isotherms for the sorption of zinc and copper onto kaolinite; comparison of various error functions," International Journal of Environmental Science \& Technology, vol. 11, pp. 111-119, 2014.

[5] T. Shah, and K. Saeed, "Experimental study on silver nanoparticles: synthesis, photo-degradation and analysis", Journal of Advances in Science \& Engineering, vol. 3, no. 1, pp. 37-42, 2020.

[6] Z. Hong, L. Donghong, Z. Yan, L. Shuping, and L. Zhe, "Sorption isotherm and kinetic modeling of aniline on Crbentonite," Journal of Hazardous Materials, vol. 167, pp. 141 - 147, 2009.

[7] C. Hao, and A. Wang, "Kinetic and isothermal studies of lead ion adsorption onto polygorskite clay," Journal of Colloid \& Interface Science, vol. 307, pp. 309-316, 2007.

[8] I. Ali, O. M. L. Alharbi, A. Tkachev, E. Galunin, A. Burakov, V. A. Grachev, "Water treatment by new-generation graphene materials: hope for bright future," Environmental Science \& Pollution Research, vol. 25, pp. 7315-7329, 2018.

[9] I. Ali, O. M. L. Alharbi, Z. A. ALOthman, and A. Alwarthan, "Facile and eco-friendly synthesis of functionalized iron nanoparticles for cyanazine removal in water," Colloids \& Surfaces B: Biointerfaces, vol. 171, pp. 606-613, 2018.

[10] E. A. Burakova, T. P. Dyachkova, A. V. Rukhov, E. N. Tugolukov, E. V. Galunin, A. G. Tkachev, and A. A. Basheer, I. Ali, "Novel and economic method of carbon nanotubes synthesis on a nickel magnesium oxide catalyst using microwave radiation," Journal of Molecular Liquids, vol. 253, pp. 340-346, 2018.

[11] I. Ali, O. M. L. Alharbi, Z. A. ALOthman, A. M. Al-Mohaimeed, and A. Alwarthan, "Modeling of fenuron pesticide adsorption on CNTs for mechanistic insight and removal in water," Environmental Research, vol. 170, pp. 389-397, 2019.

[12] I. R. Ilaboya, E. O. Oti, G. O. Ekoh, and L. O. Umukoro, "Performance of activated carbon from cassava peels for the treatment of effluent wastewater," Iranica Journal of Energy \& Environment, vol. 4, no. 4, pp. 361-375, 2013.

[13] I. Ali, O. M. L. Alharbi, Z. A. ALOthman, and A. Y. Badjah, "Kinetics, thermodynamics, and modeling of amido black dye photodegradation in water using Co/TiO2 nanoparticles," Photochemistry \& Photobiology, vol. 94, pp. 935-941, 2018.

[14] I. Ali, O. M. L. Alharbi, Z. A. ALOthman, A. Alwarthan, and A. M. Al-Mohaimeed, "Preparation of a carboxymethylcellulose-iron composite for uptake of atorvastatin in water," International Journal of Biological Macromolecule, vol. 132, pp. 244-253, 2019.

[15] I. Ali, S. Afshinb, Y. Poureshgh, A. Azari, Y. Rashtbari, A. Feizizadeh, et al., "Green preparation of activated carbon from pomegranate peel coated with zero-valent iron nanoparticles (nZVI) and isotherm and kinetic studies of amoxicillin removal in water," Environmental Science \& Pollution Research, vol. 27, pp. 36732-36743, 2020.

[16] I. Ali, A. V. Babkin, I. V. Burakova, A. E. Burakov, E. A. Neskoromnaya, A. G. Tkachev, et al., "Fast removal of samarium ions in water on highly efficient nanocomposite-based graphene oxide modified with polyhydroquinone: Isotherms, kinetics, thermodynamics and desorption," Journal of Molecular Liquids, vol. 329, 115584, 2021 , https://doi.org/10.1016/j.molliq.2021.115584.

[17] I. Ali, T. Kon'kova, V. Kasianov, A. Rysev, S. Panglisch, X.Y. Mbianda, et al., "Preparation and characterization of nano-structured modified montmorillonite for dioxidine antibacterial drug removal in water," Journal of Molecular Liquids, vol. 331, 115770, 2021, https://doi.org/10.1016/j.molliq.2021.115770.

[18] G. B. Krishna, and S. G. Susmita, "Adsorption of chromium (VI) from water by clays,” Industrial \& Engineering Chemical Resources Journal, vol. 45, pp. 7232-7240, 2006.

[19] I. R. Ilaboya, and E. A. Otuaro, Studies on the Performance of Shale and Bentonite for the Removal Cr3+ and Mn2+ ions from Wastewater using Batch Experimental Techniques and Inferential Statistics, Journal of Environmental \& Earth Sciences, vol. 9, no. 10, pp. 131-145, 2019

[20] N. O. Omisanya, C. O. Folayan, S. Y. Aku, and S. S. Adefila, "Synthesis and characterization of zeolite for adsorption refrigeration application," Advances in Applied Science Research, vol. 3, no. 6, pp. 3746-3754, 2012.

[21] M. A. O. Badmus, T. O. K. Audu, and B. U. Anyata, "Removal of lead ion from industrial wastewaters by activated carbon from periwinkle shells," Turkish Journal of Engineering \& Environmental Science, pp. 251-263, 2007. 
[22] I. R. Qadeer, and J. Hanif, "Kinetics of zirconium ions adsorption on activated charcoal from aqueous solution," American Journal of Biochemistry \& Biotechnology, vol. 3, no. 2, pp. 34 - 43, 1994.

[23] H. Jing, H. Song, Z. Liang, G. Fuxing, and H. O. Yuh-Shan, "Equilibrium and thermodynamics parameters of adsorption of methylene blue onto rectorite," Fresenius Environmental Bulletin, vol. 19, no. 11a, pp. 2651-2656, 2010.

[24] C. H. Weng, C. Z. Tsai, S. H. Chu, and Y. C. Sharma, "Adsorption characteristics of copper (II) onto spent activated clay,” Separation Purification Technology Journal, vol. 54, pp. 187-197, 2007. 